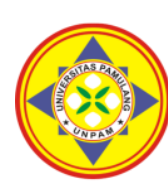

\title{
PENGARUH KETERAMPILAN KERJA DAN LINGKUNGAN KERJA TERHADAP KINERJA KARYAWAN PADA PT. GARUDA DAYA PRATAMA SEJAHTERA (GARUDA INDONESIA GROUP)
}

\author{
${ }^{1 *}$ Endang Kustini, ${ }^{2}$ Dini Ayu Utami, ${ }^{3}$ Denok Sunarsi, ${ }^{4}$ Nurjaya \\ 1.2.3 Universitas Pamulang, Tangerang Selatan, Banten, Indonesia \\ ${ }^{4}$ Universitas Suryakancana, Cianjur, Jawa Barat, Indonesia \\ *dosen01518@unpam.ac.id
}

\begin{abstract}
Abstrak
Penelitian ini bertujuan untuk mengetahui pengaruh Keterampilan Kerja dan Lingkungan Kerja Terhadap Kinerja Karyawan Pada PT. Garuda Daya Pratama Sejahtera (Garuda Indonesia Group). Penelitian ini termasuk penelitian asosiatif kausal dengan menggunakan pendekatan kuantitatif. Sampel dalam penelitian ini sebanyak 38 karyawan. Teknik sampel yang digunakan Sampling Sederhana (Simple Random Sampling) Sampel acak sederhana sehingga diperoleh sampel sebanyak 38 orang. Data dikumpulkan dengan kuesioner yang telah diuji validitas dan reliabilitasnya. Teknik analisis data yang digunakan adalah regresi berganda. Hasil dari penelitian ini yaitu berdasarkan tabel output SPSS, diketahui nilai Sig. adalah sebesar 0,00. Karena nilai Sig. $0,00<0,05$, maka sesuai dengan dasar pengambilan keputusan dalam uji $\mathrm{F}$ dapat disimpulkan bahwa hipotesis diterima atau dengan kata lain Keterampilan Kerja (X1), Lingkungan Kerja (X2) secara simultan berpengaruh terhadap Kinerja Karyawan dan berdasarkan tabel output SPSS, diketahui nilai F hitung adalah sebesar 20.788. Karena nilai F hitung 20.788 > F Tabel 3.26, maka sebagaimana dasar pengambilan keputusan dalam uji F dapat disimpulkan bahwa hipotesis diterima atau dengan kata lain Keterampilan Kerja (X1), Lingkungan Kerja (X2) secara simultan berpengaruh terhadap Kinerja Karyawan (Y).
\end{abstract}

Kata Kunci: Keterampilan, Lingkungan, Kinerja Karyawan

\section{Abstract}

This study aims to determine the effect of work skills and work environment on employee performance at PT. Garuda Daya Pratama Sejahtera (Garuda Indonesia Group). This research includes causal associative research using a quantitative approach. The sample in this study were 38 employees. The sampling technique used is Simple Random Sampling. A simple random sample is used to obtain a sample of 38 people. Data were collected by using a questionnaire that had been tested for validity and reliability. The data analysis technique used is multiple regression. The results of this study are based on the SPSS output table, it is known that the value of Sig. is 0.00 . Because the value of Sig. $0.00<0.05$, then according to the basis of decision making in the F test it can be concluded that the hypothesis is accepted or in other words Work Skills (X1), Work Environment (X2) simultaneously affect Employee Performance and based on the SPSS output table, it is known the calculated F value is 20,788. Because the calculated $F$ value is 20,788 > F Table 3.26, then as the basis for decision making in the F test, it can be concluded that the hypothesis is accepted or in other words Work Skills (X1), Work Environment (X2) simultaneously affects Employee Performance $(Y)$.

Keywords: Skills, Environment, Employee Performance

\section{PENDAHULUAN}

Pengelolaan sumber daya manusia sendiri sangat penting dalam suatu perusahaan di samping faktor lainnya seperti modal. Karena pengelolaan SDM sendiri untuk mendapatkan karyawan-karyawan yang handal dan mampu melaksanakan tugasnya secara benar dan tanggung jawab yang dapat meningkatkan efektifitas organisasi dalam rangka mencapai tujuan.

Di dalam pengelolaan SDM, apabila individu dalam organisasi yaitu sumber daya manusianya dapat berjalan efektif maka organisasi tetap berjalan efektif. Beberapa kegiatan pengelolaan SDM misalnya 
pengadaan, penilaian, perlindungan, memotivasi karyawan, memberdayakan pegawai, peningkatan disiplin, bimbingan, dan lain-lain. Pengelolaan dan pengoptimalan sumber dayan manusia tidak lepas dari faktor karyawan. Organisasi harus mempunyai karyawan- karyawan mempunyai kinerja yang baik. Dengan kata lain kelangsungan suatu organisasi ditentukan oleh kinerja karyawannya.

Dari beberapa faktor yang di temukan, untuk meningkatkan kinerja karyawan salah satunya adalah dengan memperhatikan faktor lingkungan kerja. Organisasi selaku induk kerja harus menyediakan lingkungan kerja yang nyaman dan kondusif yang mampu memancing para karyawan untuk bekerja dengan produktif. Penyediaan lingkungan kerja secara nyaman akan mampu memberikan kepuasan kepada karyawan terhadap pekerjaan yang dilakukan dan memberikan kesan yang mendalam bagi karyawan yang pada akhirnya karyawan akan mempunyai kinerja yang baik.

Kondisi lingkungan kerja yang tidak sehat dapat menyebabkan para karyawan mudah stres, tidak semangat untuk bekerja, datang terlambat, demikian juga sebaliknya apabila lingkungan kerja itu sehat maka para karyawan tentunya akan semangat dalam bekerja, tidak mudah sakit, mudah untuk konsentrasi, sehingga pekerjaan menjadi cepat selesai sesuai dengan target. Lingkungan kerja sendiri mempunyai dua dimensi, yaitu dimensi fisik (pewarnaan ruangan, pencahayaan, kebersihan, tata ruang, dan lain-lain) dan dimensi non fisik (kesejahteraan karyawan, suasana kerja, hubungan antar karyawan, dan lain-lain). Organisasi harus mampu menyediakan kedua dimensi tersebut dalam keadaan baik sehingga mampu membuat para karyawan untuk tetap bekerja dengan produktif dan saling bekerja sama antar karyawan maupun dengan pimpinan untuk mencapai tujuan organisasi.

Kinerja merupakan suatu fungsi dari motivasi dan kemampuan untuk menyelesaikan tugas atau pekerjaan seseorang sepatutnya memiliki derajat kesediaan dan tingkat kemampuan tertentu.
Kesediaan dan keterampilan seseorang tidaklah cukup efektif untuk mengerjakan sesuatu tanpa pemahaman yang jelas tentang apa yang akan dikerjakan dan bagaimana mengerjakannya. Kinerja merupakan perilaku nyata yang ditampilkan setiap orang sebagai prestasi kerja yang dihasilkan oleh karyawan sesuai dengan prestasi kerja yang dihasilkan oleh karyawan sesuai dengan pernyataan dalam perusahaan. Kinerja karyawan merupakan suatu hal yang sangat penting dalam upaya perusahaan untuk mencapai tujuannya.

PT. Garuda Daya Pratama Sejahtera (Garuda Indonesia Group) adalah anak perusahaan pertama dari PT. Garuda Maintenance Facility Aero Asia Tbk dan kedua perusahaan tersebut masih dalam organisasi dari PT. Garuda Indonesia Group. PT. Garuda Daya Pratama Sejahtera (Garuda Indonesia Group) merupakan perusahaan yang bergerak dalam bidang jasa penyediaan tenaga kerja professional. Adapun jasa tenaga kerja yang disediakan antara lain aircraft technician assistance, aircraft ground handling, aircraft painter, administration, front office, aviation security, building management, IT support, medical dan aircraft cleaning. Sebuah jasa yang dikerjakan berdasarkan permintaan tentunya memiliki nilai komitmen yang cukup tinggi, maka akan sangat memperhatikan kualitas kerja dari setiap karyawan yang ada dengan melakukan penilaian kinerja. Berdasarkan observasi peneliti sebelumnya peneliti menemukan masalah seperti karyawan tidak mematuhi dan mengindahkan SOP perusahaan yang ada sehingga menurunnya kinerja karyawan PT. Garuda Daya Pratama Sejahtera (Garuda Indonesia Group) dalam melakukan penilaian kinerja karyawan PT. Garuda Daya Pratama Sejahtera (Garuda Indonesia Group) melakukan review penilaian kinerja karyawan menggunakan form penilaian yang akan dilakukan 3 bulan sekali, berikut adalah lampiran form penilaian kinerja karyawan yang dilakukan PT. Garuda Daya Pratama Sejahtera (Garuda Indonesia Group). Keadaan lingkungan kerja di PT. Garuda Daya Pratama Sejahtera (Garuda Indonesia Group) belum mendukung karyawan untuk bekerja dengan 
nyaman, itu terlihat dengan ada banyaknya file-file (surat, form absensi karyawan, form lemburan karyawan) yang berserakan disekitar tempat kerja karyawan, suhu ruangan yang belum menentu hampir diseluruh ruang kerja karyawan yang disebabkan belum tersedianya pengatur suhu ruangan, luas ruang kerja yang kurang memadai sehingga membatasi ruang gerak karyawan, masih adanya kecemburuan antar karyawan mengenai pembagian tugas, dan lain-lain. Selain itu kinerja karyawan juga masih belum sesuai dengan harapan manajemen, bisa terlihat ketika karyawan tidak bisa memenuhi target selesainya tugas yang seharusnya sesuai deadline. Tentunya masalah-malasah seperti di atas harus segera diperbaiki agar tidak menghambat kepada visi dan misi PT. Garuda Daya Pratama Sejahtera (Garuda Indonesia Group).

Berdasarkan pernyataan-pernyataan di atas, maka penulis tertarik untuk mengadakan penelitian yang berjudul "Pengaruh Keterampilan Kerja dan Lingkungan Kerja Terhadap Kinerja Karyawan pada PT. Garuda Daya Pratama Sejahtera (Garuda Indonesia Group)". Penelitian ini diharapkan dapat memberikan kebermanfaatannya dalam membangun kinerja karyawan agar visi dan misi PT. Garuda Daya Pratama Sejahtera (Garuda Indonesia Group) dapat tercapai.

\section{TINJAUAN PUSTAKA}

\section{Linkungan Kerja}

Pengertian lingkungan kerja menurut Armstrong (Kisworo, 2012), "the work environment consist of the system of work, the design of jobs, working conditions, and the ways in which people are treated at work by their managers and co-workers". Lingkungan kerja terdiri dari sistem kerja, desain pekerjaan, kondisi kerja, dan cara-cara di mana orang diperlakukan di tempat kerja dengan manajer mereka dan rekan kerja. Menurut (Nitisemito, 2016) adalah "segala sesuatu yang ada disekitar pekerja dan dapat mempengaruhi mereka dalam menjalankan tugas-tugas yang dibebankan". Menurut (Sedarmayati, 2001), mendefinisikan lingkungan kerja adalah keseluruhan alat perkakas dan bahan yang dihadapi, lingkungan sekitarnya di mana seseorang bekerja, metode kerjanya, serta pengaturan kerjanya baik sebagai perseorangan maupun sebagai kelompok.

\section{Keterampilan Kerja}

Keterampilan berasal dari kata terampil yang berarti cakap, mampu, dan cekatan. (Iverson, 2016) mengatakan "keterampilan membutuhkan pelatihan dan kemampuan dasar yang dimiliki setiap orang dapat lebih membantu menghasikan sesuatu yang lebih bernilai dengan lebih cepat".

Menurut (Notoadmodjo, 2017) mengatakan "keterampilan merupakan aplikasi dari pengetahuan sehingga tingkat keterampilan seseorang berkaitan dengan tingkat pengetahuan, dan pengetahuan dipengaruhi oleh Tingkat Pendidikan, Umur, Pengalaman". Sedangkan faktor-faktor yang dapat mempengaruhi keterampilan secara langsung menurut (Widyatun, 2015), yaitu Motivasi, Pengalaman, dan Keahlian.

3. Kinerja

Istilah kinerja berasal dari kata Job performance atau actual performance (prestasi kinerja atau prestasi sesungguhnya yang dicapai seseorang). Pengertian kinerja (prestasi kerja) adalah "Hasil kerja secara kualitas dan kuantitas yang dicapai oleh seorang pegawai dalam melaksanakan tugasnya sesuai dengan tanggung jawab yang diberikan kepadanya" (Mangkunegara, 2017).

(Hasibuan, 2017) mengemukakan "kinerja (prestasi kerja) adalah suatu hasil kerja yang dicapai seseorang dalam melaksanakan tugas-tugas yang dibebankan kepadanya yang didasarkan atas kecakapan pengalaman dan kesungguhan serta waktu".

Menurut (Rivai, 2015) kinerja "Merupakan suatu fungsi dari motivasi dan kemampuan". Untuk menyelesaikan 
tugas atau pekerjaan seseorang sepatutnya memiliki derajat kesediaan dan tigkat kemampuan tertentu. Kesediaan dan keterampilan sesorang tidaklah cukup efektif untuk mengerjakan sesuatu tanpa pemahaman yang jelas tentang apa yang akan dikerjakan dan bagaimana mengerjakannya. Kinerja merupakan perilaku nyata yang ditampilkan setiap orang sebagai prestasi kerja yang dihasilkan oleh karyawan sesuai dengan prestasi kerja yang dihasilkan oleh karyawan sesuai dengan pernytaan dalam perusahaan. Kinerja karyawan merupakan suatu hal yang sangat penting dalam upaya perusahaan untuk mencapai tujuannya.

\section{METODE}

Populasi dalam penelitian ini berjumlah 60 responden PT. Garuda Daya Pratama Sejahtera (Garuda Indonesia Group) sebanyak 60 orang. Teknik pengambilan sampling dalam penelitian ini adalah sampel jenuh, dimana semua anggota populasi dijadikan sebagai sampel. Dengan demikian sampel dalam penelitian ini sampel yang digunakan berjumlah 60 responden. Jenis penelitian yang dipakai adalah asosiatif, dimana tujuannya adalah untuk mengetahui atau mencari keterhubungan antara variabel independen terhadap variabel dependennya. Dalam menganalisis data digunakan uji validitas, uji reliabilitas, analisis regresi linier sederhana, analisis koefisien korelasi, analisis koefisien determinasi dan pengujian hipotesis.

\section{HASIL DAN PEMBAHASAN}

\section{Analisis Regresi Linear Berganda}

Analisis regresi merupakan suatu metode atau teknik analisis hipotesis penelitian untuk menguji ada tidaknya pengaruh antara variabel satu dengan variabel lain yang dinyatakan dalam bentuk persamaan matematik (regresi). Analisis regresi linear multiples atau berganda berfungsi untuk mencari pengaruh dari dua atau lebih variabel independent (variabel bebas atau $X$ ) terhadap variabel dependent (variabel terikat atau $\mathrm{Y}$ ).

Tabel 1. Hasil Analisis Regresi Linear Berganda

Coefficients $^{\mathrm{a}}$

\begin{tabular}{|c|c|c|c|c|c|c|}
\hline \multirow[b]{2}{*}{ Mod } & & \multicolumn{2}{|c|}{ Unstandardized Coefficients } & \multirow{2}{*}{$\begin{array}{c}\text { Standardized } \\
\text { Coefficients } \\
\text { Beta }\end{array}$} & \multirow[b]{2}{*}{$\mathrm{t}$} & \multirow[b]{2}{*}{ Sig. } \\
\hline & & $\mathrm{B}$ & Std. Error & & & \\
\hline \multirow[t]{3}{*}{1} & (Constant) &,- 697 & 5,865 & &,- 119 &, 906 \\
\hline & Keterampilan Kerja & , 106 &, 129 & 098 & 819 & .418 \\
\hline & Lingkungan Kerja & ,331 & ,056 &, 702 & 5,862 &, 000 \\
\hline
\end{tabular}

a. Dependent Variable: Kinerja Karyawan

Tabel "Coefficients" memberikan informasi tentang persamaan regresi dan ada tidaknya pengaruh variabel Keterampilan Kerja, Lingkungan Kerja secara parsial (sendiri-sendiri) terhadap variabel Kinerja Karyawan. Adapun

rumus persamaan regresi dalam analisis atau penelitian ini adalah sebagai berikut:

$$
\begin{aligned}
& Y=a+b 1 \times 1+b 2 \times 2 \\
& Y=(-697)+0.106+0.331
\end{aligned}
$$

\section{Analisis Kolerasi Berganda}

Tabel 2. Hasil Analisis Kolerasi Berganda

\begin{tabular}{|c|c|c|c|c|}
\hline & & $\begin{array}{c}\text { Keterampilan } \\
\text { Kerja }\end{array}$ & $\begin{array}{c}\text { Lingkungan } \\
\text { Kerja }\end{array}$ & $\begin{array}{l}\text { Kinerja } \\
\text { Karyawan }\end{array}$ \\
\hline \multirow[t]{3}{*}{ Keterampilan Kerja } & Pearson Correlation & 1 & ,298 & .307 \\
\hline & Sig. (2-tailed) & & .070 & .061 \\
\hline & $\mathrm{N}$ & 38 & 38 & 38 \\
\hline \multirow[t]{3}{*}{ Lingkungan Kerja } & Pearson Correlation & .298 & 1 & $.731^{\star x}$ \\
\hline & Sig. (2-tailed) & .070 & & .000 \\
\hline & $N$ & 38 & 38 & 38 \\
\hline \multirow[t]{3}{*}{ Kinerja Karyawan } & Pearson Correlation & .307 & $.731^{\star \star}$ & 1 \\
\hline & Sig. (2-tailed) & .061 &, 000 & \\
\hline & $\mathrm{N}$ & 38 & 38 & 38 \\
\hline
\end{tabular}

\section{Correlations}


Berdasarkan tabel output di atas, peneliti akan melakukan penarikan kesimpulan dengan merujuk pada ke-3 dasar pengambilan keputusan dalam analisis korelasi bivariate pearson diatas.

1. Berdasarkan Nilai Signifikasi Sig. (2-tailed)

Dari tabel output di atas diketahui nilai Sig. (2-tailed) antara Keterampilan Kerja (X1) Dengan Kinerja Karyawan (Y) adalah sebesar $0.06>0.05$, yang berarti tidak terdapat korelasi yang signifikan antara Variabel Keterampilan Kerja terhadap Variabel Kinerja Karyawan.

Selanjutnya, hubungan antara Lingkungan Kerja (X2) dengan Kinerja Karyawan (Y) memiliki nilai Sig. (2-tailed) sebesar $0.00<0.05$, yang berarti terdapat korelasi yang signifikan antara variabel Lingkungan Kerja dengan variabel Kinerja Karyawan.

2. Berdasarkan Nilai $r$ hitung (Pearson Correlations)
Diketahui nilai $r$ hitung untuk hubungan Keterampilan Kerja (X1) dengan Kinerja Karyawan (Y) adalah sebesar 0.307 $<\mathrm{r}$ tabel 0.320, maka dapat disimpulkan bahwa tidak ada hubungan atau korelasi antara variabel Keterampilan Kerja dengan Kinerja Karyawan.

Selanjutnya, diketahui nilai $r$ hitung untuk hubungan Lingkungan Kerja (X2) dengan Kinerja Karyawan (Y) adalah sebesar $0.731>\mathrm{r}$ tabel 0.320 , maka dapat disimpulkan bahwa ada hubungan atau korelasi antara variabel Lingkungan Kerja dengan Variabel Kinerja Karyawan.

Karena $r$ hitung atau Pearson Correlations dalam analisis ini bernilai positif maka itu artingan hubungan antara kedua variabel tersebut bersifat positif atau dengan kata lain semakin naiknya Keterampilan Kerja, Lingkungan Kerja maka akan meningkat pula Kinerja Karyawan.

\section{Koefisien Determinasi}

Tabel 3. Hasil Koefisien Determinasi

Model Summary

\begin{tabular}{|c|c|c|c|c|}
\hline Model & $\mathrm{R}$ & R Square & $\begin{array}{c}\text { Adjusted R } \\
\text { Square }\end{array}$ & $\begin{array}{l}\text { Std. Error of } \\
\text { the Estimate }\end{array}$ \\
\hline 1 &, $737^{a}$ &, 543 &, 517 & 2,165 \\
\hline
\end{tabular}

Berdasarkan table output SPSS

"Model Summary" di atas, diketahui nilai koefisien determinasi atau R Square sebesar 0,543 . Besarnya angka koefisien determinasi (R Square) adalah 0,543 atau sama dengan 54,3\%. Angka tersebut mengandung arti bahwa variabel
Keterampilan Kerja (X1), variabel Lingkungan Kerja (X2) berpengaruh terhadap variabel Kinerja Karyawan $(\mathrm{Y})$ sebesar $54,3 \%$ sedangkan sisanya (100\% $54,3 \%=45,7 \%$ ) dipengaruhi oleh variabel lain diluar persamaan regresi ini atau variabel yang tidak diteliti.

\section{Uji Hipotesis}

\section{a. Uji T}

Tabel 4. Hasil Uji T

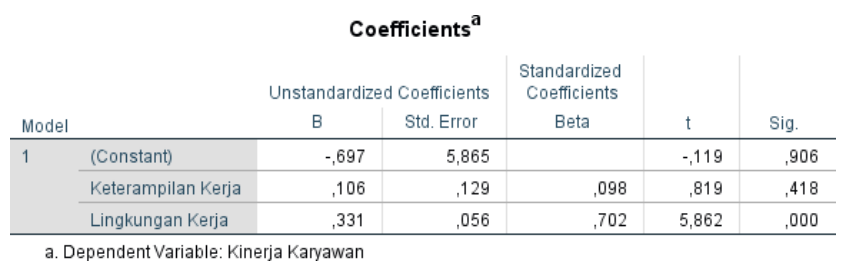


Uji T pertama dilakukan untuk mengetahui apakah ada pengaruh Keterampilan Kerja (X1) terhadap Kinerja Karyawan (Y).

1. Berdasarkan Nilai Signifikasi (Sig.) Berdasarkan tabel output SPSS "Coefficients" di atas diketahui nilai Signifikansi (Sig) variabel Keterampilan Kerja (X1) adalah sebesar 0,418 . Karena nilai Sig. 0,418 > probabilitas 0,05, maka dapat disimpulkan bahwa $\mathrm{H} 1$ atau hipotesis pertama ditolak. Artinya tidak ada pengaruh Keterampilan Kerja (X1) terhadap Keputusan Pembelian (Y).

2. Berdasarkan Nilai thitung dengan $t$ tabel

Berdasarkan output SPSS diatas diketahui nilai $\mathrm{T}$ hitung variabel Keterampilan Kerja adalah sebesar $0.819<\mathrm{T}$ tabel 2.030, maka dapat disimpulkan bahwa $\mathrm{H} 1$ atau hipotesis pertama ditolak. Artinya tidak ada pengaruh Keterampilan Kerja (X1) terhadap Kinerja Karyawan (Y).
UjiT kedua dilakukan untuk mengetahui apakah ada pengaruh Lingkungan Kerja (X2) terhadap Kinerja Karyawan (Y).

1. Berdasarkan Nilai Signifikasi (Sig.) Berdasarkan tabel output SPSS "Coefficients" di atas diketahui nilai Signifikansi (Sig) variabel Lingkungan Kerja (X2) adalah sebesar 0,220. Karena nilai Sig. $0,00<$ probabilitas 0,05 , maka dapat disimpulkan bahwa $\mathrm{H} 2$ atau hipotesis kedua diterima. Artinya ada pengaruh Lingkungan Kerja (X2) terhadap Kinerja Karyawan (Y).

2. Berdasarkan Nilai t hitung dengan $t$ tabel

Berdasarkan output SPSS diatas diketahui nilai $\mathrm{T}$ hitung variabel Lingkungan Kerja adalah sebesar $5.862>$ T tabel 2.030 maka dapat disimpulkan bahwa $\mathrm{H} 2$ atau hipotesis kedua diterima. Artinya ada pengaruh Lingkungan Kerja (X2) terhadap Kinerja Karyawan $(\mathrm{Y})$.

\section{b. Uji F}

Tabel 5. Hasil Uji F

ANOVA $^{\text {a }}$

\begin{tabular}{|c|c|c|c|c|c|c|}
\hline Model & & $\begin{array}{l}\text { Sum of } \\
\text { Squares }\end{array}$ & df & Mean Square & $\mathrm{F}$ & Sig. \\
\hline \multirow[t]{3}{*}{1} & Regression & 194,944 & 2 & 97,472 & 20,788 &, $000^{b}$ \\
\hline & Residual & 164,109 & 35 & 4,689 & & \\
\hline & Total & 359,053 & 37 & & & \\
\hline
\end{tabular}

1. Berdasarkan Nilai Signifikasi (Sig.) Kinerja Karyawan.

dari Output Anova

Berdasarkan tabel output

2. Berdasarkan Perbandingan Nilai F Hitung dengan F Tabel Berdasarkan tabel output SPSS di atas, diketahui nilai $F$ hitung adalah sebesar 20.788. Karena nilai F hitung $20.788>$ F Tabel 3.26, maka sebagaimana dasar pengambilan keputusan dalam uji $\mathrm{F}$ dapat disimpulkan bahwa hipotesis diterima atau dengan kata lain Keterampilan Kerja (X1), Lingkungan Kerja (X2) secara 
simultan berpengaruh terhadap Kinerja Karyawan (Y).

\section{Pembahasan Penelitian}

\section{a. Pengaruh Keterampilan Kerja Terhadap Kinerja Karyawan}

Berdasarkan data penelitian yang telah dilakukan di atas dapat diperoleh hasil sebagai berikut :

1) Dengan menggunakan rumus koefisien regresi dapat diketahui variabel Koefisien regresi variabel Keterampilan Kerja (X1) sebesar 0.106 artinya jika variabel independen lain nilainya tetap dan Keterampilan Kerja mengalami kenaikan 1\%, maka Kinerja Karyawan (Y) akan mengalami kenaikan sebesar 0.106. Koefisien bernilai positif artinya terjadi hubungan positif antara Keterampilan Kerja dengan Kinerja Karyawan.

2) Dengan menggunakan analisis kolerasi bivariate pearson dapat nilai nilai Sig. (2-tailed) antara Keterampilan Kerja (X1) Dengan Kinerja Karyawan (Y) adalah sebesar $0.06>0.05$, yang berarti tidak terdapat korelasi yang signifikan antara Variabel Keterampilan Kerja terhadap Variabel Kinerja Karyawan.

3) Dengan menggunakan uji $\mathrm{T}$ dapat diketahui apakah ada pengaruh Keterampilan Kerja (X1) terhadap Kinerja Karyawan (Y)

a) Berdasarkan tabel output SPSS "Coefficients" di atas diketahui nilai Signifikansi (Sig) variabel Keterampilan Kerja (X1) adalah sebesar 0,418. Karena nilai Sig. 0,418 > probabilitas 0,05, maka dapat disimpulkan bahwa H1 atau hipotesis pertama ditolak. Artinya tidak ada pengaruh Keterampilan Kerja (X1) terhadap Keputusan Pembelian (Y).

b) Berdasarkan output SPSS diatas diketahui nilai $\mathrm{T}$ hitung valiabel
Keterampilan Kerja adalah sebesar $0.819<\mathrm{T}$ tabel 2.030, maka dapat disimpulkan bahwa H1 atau hipotesis pertama ditolak.

Artinya tidak ada pengaruh Keterampilan Kerja (X1) terhadap Kinerja Karyawan (Y).

\section{b. Pengaruh Lingkungan Kerja} Terhadap Kinerja Karyawan

Berdasarkan data penelitian yang telah dilakukan di atas dapat diperoleh hasil sebagai berikut:

1) Dengan menggunakan rumus koefisien regresi dapat diketahui variabel Lingkungan Kerja (X2) sebesar 0.331 artinya jika variabel independen lain nilainya tetap dan Lingkungan Kerja mengalami kenaikan 1\%, maka Kinerja Karyawan (Y) akan mengalami kenaikan sebesar 0.331 . Koefisien bernilai positif artinya terjadi hubungan positif antara Lingkungan Kerja dengan Kinerja Karyawan.

2) Dengan menggunakan analisis kolerasi bivariate pearson dapat diketahui hubungan antara Lingkungan Kerja (X2) dengan Kinerja Karyawan (Y) memiliki nilai Sig. (2-tailed) sebesar $0.00<$ 0.05 , yang berarti terdapat korelasi yang signifikan antara variabel Lingkungan Kerja dengan variabel Kinerja Karyawan.

3) Dengan menggunakan uji $\mathrm{T}$ dapat diketahui apakah ada pengaruh Lingkungan Kerja (X2) terhadap Kinerja Karyawan (Y)

a) Berdasarkan tabel output SPSS "Coefficients" di atas diketahui nilai Signifikansi (Sig) variabel Lingkungan Kerja (X2) adalah sebesar 0,220. Karena nilai Sig. $0,00<$ probabilitas 0,05, maka dapat disimpulkan bahwa $\mathrm{H} 2$ atau hipotesis kedua diterima.

Artinya ada pengaruh Lingkungan Kerja (X2) terhadap Kinerja Karyawan (Y). 
b) Berdasarkan output SPSS diatas diketahui nilai $\mathrm{T}$ hitung valiabel Lingkungan Kerja adalah sebesar $5.862>\mathrm{T}$ tabel 2.030 maka dapat disimpulkan bahwa $\mathrm{H} 2$ atau hipotesis kedua diterima. Artinya ada pengaruh Lingkungan Kerja (X2) terhadap Kinerja Karyawan $(Y)$.

c. Pengaruh Keterampilan Kerja dan Lingkungan Kerja Terhadap Kinerja Karyawan

Berdasarkan data penelitian yang telah dilakukan di atas dapat diperoleh hasil sebagai berikut :

1. Berdasarkan Nilai Signifikasi (Sig.) dari Output Anova

Berdasarkan tabel output SPSS di atas, diketahui nilai Sig. adalah sebesar 0,00 . Karena nilai Sig. $0,00<0,05$, maka sesuai dengan dasar pengambilan keputusan dalam uji $\mathrm{F}$ dapat disimpulkan bahwa hipotesis diterima atau dengan kata lain Keterampilan Kerja (X1), Lingkungan Kerja (X2) secara simultan berpengaruh terhadap Kinerja Karyawan.

2. Berdasarkan Perbandingan Nilai F Hitung dengan F Tabel Berdasarkan tabel output SPSS di atas, diketahui nilai $\mathrm{F}$ hitung adalah sebesar 20.788. Karena nilai F hitung $20.788>$ F Tabel 3.26, maka sebagaimana dasar pengambilan keputusan dalam uji F dapat disimpulkan bahwa hipotesis diterima atau dengan kata lain Keterampilan Kerja (X1), Lingkungan Kerja (X2) secara simultan berpengaruh terhadap Kinerja Karyawan (Y).

\section{PENUTUP}

\section{Kesimpulan}

1. Berdasarkan tabel output SPSS "Coefficients" diketahui nilai Signifikansi (Sig) variabel Keterampilan Kerja (X1) adalah sebesar 0,418. Karena nilai Sig. 0,418 > probabilitas 0,05, maka dapat disimpulkan bahwa $\mathrm{H} 1$ atau hipotesis pertama ditolak. Artinya tidak ada pengaruh Keterampilan Kerja (X1) terhadap Kinerja Karyawan (Y).

2. Berdasarkan tabel output SPSS "Coefficients" diketahui nilai Signifikansi (Sig) variabel Lingkungan Kerja (X2) adalah sebesar 0,220. Karena nilai Sig. $0,00<$ probabilitas 0,05, maka dapat disimpulkan bahwa $\mathrm{H} 2$ atau hipotesis kedua diterima. Artinya ada pengaruh Lingkungan Kerja (X2) terhadap Kinerja Karyawan (Y).

3. Berdasarkan tabel output SPSS di atas, diketahui nilai $\mathrm{F}$ hitung adalah sebesar 20.788. Karena nilai F hitung $20.788>$ F Tabel 3.26, maka sebagaimana dasar pengambilan keputusan dalam uji $\mathrm{F}$ dapat disimpulkan bahwa hipotesis diterima atau dengan kata lain Keterampilan Kerja (X1), Lingkungan Kerja (X2) secara simultan berpengaruh terhadap Kinerja Karyawan (Y).

4. Variabel Keterampilan Kerja (X1), variabel Lingkungan Kerja (X2) berpengaruh terhadap variabel Kinerja Karyawan (Y) sebesar 54,3\% sedangkan sisanya $(100 \%-54,3 \%=45,7 \%)$ dipengaruhi oleh variabel lain diluar persamaan regresi ini atau variabel yang tidak diteliti.

\section{Saran}

1. Secara teoritis, perlu penelitian yang lebih mendalam mengenai pengaruh keterampilan kerja dan lingkungan kerja terhadap kinerja karyawan. Misalnya, dengan cara mengadakan wawancara atau penyebaran kuesioner yang lebih luas guna mendapatkan hasil yang lebih maksimal.

2. Secara praktis, diperlukannya perhatian yang khusus dari pihak perusahaan pada lingkungan kerja karyawan karena lingkungan kerja yang baik dalam perusahaan dapat meningkatkan kinerja karyawan khususnya dalam poin - poin indikator lingkungan kerja terutama point yang bernilai kecil saat pengambilan kuesioner seperti pertukaran udara dan kebisingan. 
3. Secara akademis, dengan adanya penelitian ini diharapkan sebagai sebuah landasan dalam mengerjakan tugas akhir skripsi khususnya pada mahasiswa Universitas Pamulang yang ingin melakukan penelitian dengan metode kuantitatif pada variabel yang sama agar menambah variabel baru sehingga dapat memberikan data yang lebih spesifik tentang pengaruh terhadap kinerja karyawan.

\section{DAFTAR PUSTAKA}

AA. Anwar Prabu Mangkunegara. (2017). Manajemen Sumber Daya Manusia Perusahaan, Remaja Rosdakarya, Bandung.

Arikunto, S. (2013). Prosedur Penelitian: Suatu Pendekatan Praktik. Jakarta : Rineka Cipta.

Badri Munir Sukoco. (2019). Manajemen Administrasi Perkantoran Modern. Surabaya: Erlangga.

Bangun, Wilson. (2018). Manajemen Sumber Daya Manusia. Jakarta: Erlangga

Dessler, Gary. (2015). Manajemen Sumber Daya Manusia. Jakarta: Salemba Empat.

Faturrahman, M., Kahar, M. S., Arsyad, R., \& Rawi, R. D. P. (2018, July). Development of Learning Media Based on MOODLE Integrated with Blended Learning in Mathematic Learning Process at SMA Muhammadiyah Al-Amin Sorong. In IOP Conference Series: Earth and Environmental Science (Vol. 175, No. 1, p. 012202). IOP Publishing.

Gaol, CHR. Jimmy L. (2015). A to Z Human Capital (Manajemen Sumber Daya Manusia) Konsep, Teori, dan Pengembangan dalam Konteks Organisasi Publik dan Bisnis, PT. Gramedia Widiasarana, Jakarta.

Gaouzali, Saydam. (2000). Manajemen Sumber Daya Manusia (Suatu Pendekatan Mikro). Jakarta: Djambatan.

Hasibuan, Malayu S.P. (2016). Manajemen Sumber Daya Manusia. Edisi Revisi. Jakarta: Penerbit PT Bumi Aksara.
Hermawati, R., Sugiyarti, L., Handayani, R., Sunarsi, D., Alfiah, S., \& Maddinsyah, A. (2020). The Effect of Trilogy Leadership Style and Organization Culture on School Performance: Evidence form Indonesian Senior High School. PalArch's Journal of Archaeology of Egypt/Egyptology, 17(6), 8512-8537.

Ibrahim. (2018). Metodologi Penelitian Kualitatif. Bandung: Alfabeta. Iverson. (2016). Keterampilan Dasar. PT. Grapindo Persada. Jakarta.

Karlina, D. (2018). Hubungan Komunikasi Interpersonal, Disiplin Kerja Dan Lingkungan Kerja Terhadap Kinerja Pegawai Kantor Pusat LPP TVRI. JENIUS (Jurnal Ilmiah Manajemen Sumber Daya Manusia), 1(2).

Kartika, Lindawati dan Ma'arif Syamsul. (2012). Manajemen Kinerja Sumber Daya Manusia. Bogor: IPB Press

Keputusan Mentri Kesehatan Republik Indonesia Nomor 1405/MENKES/SK/XI/2002

Tentang Persyaratan Kesehatan Lingkungan Kerja Perkantoran dan Industri.

Komarudin, K. (2018). Pengaruh Lingkungan Kerja Terhadap Kinerja Karyawan Pada PT. Pos Indonesia Depok. JENIUS (Jurnal Ilmiah Manajemen Sumber Daya Manusia), 1(3).

Lewenussa, R., \& Rawi, R. D. P. (2020). Discriminant Study with Classification of Underdeveloped and Developing City Districts in West Papua Province. Ekuilibrium: Jurnal Ilmiah Bidang Ilmu Ekonomi, 15(2), 103117.

Marihot Tua Efendi. (2018). Manajemen Sumber Daya Manusia. Jakarta: PT Grasindo.

Marwansyah. (2014). Manajemen Sumber Daya Manusia, Bandung: ALFABETA.

Meilawati, D., Rawi, R. D. P., Lewenussa, R., \& Bintari, W. C. (2019). Pengaruh Pemberian Insentif Terhadap Kinerja Karyawan Pada Pt Telesindoshop 
kota

Sorong. Manajemen

Dewantara, 3(1), 128-137.

Nitisemito, Alex S. (2016). Manajemen Personalia (Manajemen Sumber Daya Manusia). Jakarta: Ghalia Indonesia.

Notoatmodjo, Soekidjo. (2017). Pendidikan dan Perilaku Kesehatan. Jakarta. Rineka Cipta.

Pawar, A., Sudan, K., Satini, S., \& Sunarsi, D. (2020). Organizational Servant Leadership. International Journal of Educational Administration, Management, and Leadership, 63-76.

Rawi, R. D. P. (2017). Analisis Hubungan Motivasi Terhadap Kinerja Pegawai (Studi Kasus Pada Kantor Kecamatan Ruing Kabupaten Ngada Ntt). Jurnal Noken: Ilmu-Ilmu Sosial, 2(2), 15-28.

Robert L. Mathis - John H. Jackson. (2016). Human Resource Management, edisi 10, Jakarta : Salemba Empat.

Salim, A. O., \& Rawi, R. D. P. (2020). Pengaruh Jaminan Sosial Tenaga Kerja Terhadap Produktivitas Kerja Karyawan Pada PT Sumber Abadi Indonesia Cabang Kota Sorong Papua Barat. Jurnal Ilmiah Manajemen Emor (Ekonomi Manajemen Orientasi Riset), 4(1), 32-40.

Sedarmayanti. (2001). Sumber Daya Manusia dan Produktivitas Kerja. Bandung : Mandar Maju.
Siagian, Sondang., P. (2018). Manajemen Sumber Daya Manusia (Edisi Pertama). Jakarta: Binapura Aksara.

Sinambela, Poltak. Lijan. (2017). Manajemen Sumber Daya Manusia. Jakarta: PT Bumi Aksara

Sugiyono. (2017). Metode Penelitian Kuantitatif, Kualitatif, dan RED. Bandung : Alfabeta

Sunarsi, D., Wijoyo, H., Prasada, D., \& Andi, D. (2020, September). Pengaruh lingkungan kerja terhadap kinerja karyawan pada pt. Mentari persada di jakarta. In Seminar Nasional Manajemen, Ekonomi, Akuntansi (Vol. 5, No. 1, pp. 117-123).

Sutrisno, Edy. (2015). Manajemen Sumber Daya Manusia(Cetakan ke tujuh). Jakarta: Kencana Prenada Media Group.

Veithzal Rivai. (2014). Manajemen Sumber Daya Manusia untuk Perusahaan, Edisi ke 6, PT. Raja Grafindo Persada, Depok, 16956

Widyatun, T. (2015). Ilmu Perilaku. Pengajar, Jakarta Pusat.

Wirawan. (2015). Evaluasi Kinerja Sumber Daya Manusia: Teori, Aplikasi, dan Penelitian. Jakarta: Salemba Empat

Yani. M. (2012). Manajemen Sumber Daya Manusia. Jakarta. Mitra Wacana Media. 